\title{
IDH2 NM_002168.3:C.419G>A
}

National Cancer Institute

\section{Source}

National Cancer Institute. IDH2 NM 002168.3:C.419G>A. NCI Thesaurus. Code C160659.

A nucleotide substitution at position 419 of the coding sequence of the IDH2 gene where guanine has been mutated to adenine. 